\title{
Body mass regulation at altitude
}

Citation for published version (APA):

Westerterp, K. R., \& Kayser, B. (2006). Body mass regulation at altitude. European Journal of Gastroenterology \& Hepatology, 18(1), 1-3. https://doi.org/10.1097/00042737-200601000-00001

Document status and date:

Published: 01/01/2006

DOI:

10.1097/00042737-200601000-00001

Document Version:

Publisher's PDF, also known as Version of record

Document license:

Taverne

Please check the document version of this publication:

- A submitted manuscript is the version of the article upon submission and before peer-review. There can be important differences between the submitted version and the official published version of record.

People interested in the research are advised to contact the author for the final version of the publication, or visit the DOI to the publisher's website.

- The final author version and the galley proof are versions of the publication after peer review.

- The final published version features the final layout of the paper including the volume, issue and page numbers.

Link to publication

\footnotetext{
General rights rights.

- You may freely distribute the URL identifying the publication in the public portal. please follow below link for the End User Agreement:

www.umlib.nl/taverne-license

Take down policy

If you believe that this document breaches copyright please contact us at:

repository@maastrichtuniversity.nl

providing details and we will investigate your claim.
}

Copyright and moral rights for the publications made accessible in the public portal are retained by the authors and/or other copyright owners and it is a condition of accessing publications that users recognise and abide by the legal requirements associated with these

- Users may download and print one copy of any publication from the public portal for the purpose of private study or research.

- You may not further distribute the material or use it for any profit-making activity or commercial gain

If the publication is distributed under the terms of Article $25 \mathrm{fa}$ of the Dutch Copyright Act, indicated by the "Taverne" license above, 


\section{Body mass regulation at altitude Klaas R. Westerterp ${ }^{a}$ and Bengt Kayser ${ }^{b}$}

\author{
Altitude exposure decreases energy intake and thus \\ induces an energy deficit resulting in the loss of body \\ mass. The energy deficit is worsened when energy \\ expenditure is increased by exercise because the increase \\ is not matched by an increased energy intake. The \\ indicated fuel for the optimal use of the rarefied oxygen at \\ altitude is carbohydrate. For optimal taste and maximizing \\ energy intake, fat is the best. Protein should rather be \\ limited because of its high thermic effect. Intestinal \\ malabsorption probably does not play a role in the energy \\ deficit. Even though the sensation of exertion during \\ climbing at high altitude is intense, the actual energy \\ expenditure is not high. Eur J Gastroenterol Hepatol \\ 18:1-3 (c) 2006 Lippincott Williams \& Wilkins.
}

\section{Introduction}

In this issue of the journal, Hamad and Travis [1] review the present understanding of the effects of altitude on human energy balance. They find that many studies reported a loss of body mass during high altitude sojourns. Overall, it seems that $5000-5500 \mathrm{~m}$ is an altitude limit beyond which the maintenance of body mass and body composition are challenged. The postulated mechanisms for the disturbance of the energy balance are a reduction of energy intake, a reduction of intestinal energy uptake as a result of an impaired intestinal function and increased energy expenditure. The authors discuss these mechanisms and address practical implications. The aim of this leading paper is to comment and complement the paper by Hamid and Travis [1] and to suggest further avenues for research.

\section{Energy intake}

Hamad and Travis [1] discuss several possible explanations for the reduction in energy intake at high altitude. A complementary hypothetical explanation may be a reduction in energy intake for reasons of survival. As digestion implies a considerable metabolic load on the organism, Woods [2] hypothesized that food provides a potential threat to the organism, and that intake and postprandial behaviour are controlled to limit this threat. The author also proposes that in certain circumstances these defence mechanisms may become inappropriately activated. The increased satiety scores observed at high altitude, as referred to by Hamad and Travis [1], can be explained by the modulation of energy intake under limited oxygen availability conditions. This phenomenon is comparable to that observed in chronic obstructive pulmonary disease patients who quickly feel dyspnoeic when feeding [3]. If this
European Journal of Gastroenterology \& Hepatology 2006, 18:1-3

Keywords: body weight, diet composition, energy expenditure, food intake, malabsorption

aDepartment of Human Biology, Maastricht University, The Netherlands and
b Institute of Movement Sciences and Sports Medicine, University of Geneva Switzerland.

Correspondence to Klaas R. Westerterp, Department of Human Biology, Maastricht University, PO Box 616, 6200 MD Maastricht, The Netherlands Tel: +3143 3881628; fax: +3143 3670976; e-mail: k.westerterp@hb.unimaas.nl

Received 26 September 2005 Accepted 2 October 2005

mechanism indeed plays a role at high altitude, this would imply that a low-protein diet should be used to reduce diet-induced thermogenesis and thus maintain appetite at high altitude. Thermogenesis values for nutrients are $0-3 \%$ for fat, $5-10 \%$ for carbohydrate, but as high as $20-30 \%$ for protein [4]. Obviously, in the long term, low protein diets will negatively affect protein balance. In addition, there is some evidence that hypoxia may interfere with protein synthesis. So an altitude effect on protein balance might be inevitable and will be worsened by a negative energy balance, and thus the advice would be to try and overcome at least the latter by keeping the total energy intake high. To maximize energy intake, fat is preferable for its low thermogenesis, good taste and higher energy density per gram than carbohydrate. On the other hand, oxygen consumption yields $21.1 \mathrm{~kJ} / \mathrm{l}$ for carbohydrate oxidation and $19.6 \mathrm{~kJ} / \mathrm{l}$ for fat oxidation [5]. A diet richer in carbohydrates thus requires less oxygen, possibly the most important criterion at high altitude, and should be advised. In addition, with regard to gas exchange, as correctly pointed out by Hamad and Travis [1], a diet rich in carbohydrates, as a result of an increase in the respiratory quotient, is also advantageous because, for a given carbon dioxide production, it will be accompanied by higher alveolar pressures of oxygen thus enhancing diffusion from air to blood and potentially leading to a higher saturation. It has indeed been reported that a diet high in carbohydrate may reduce the level of hypoxemia [6]. On the other hand, this may not necessarily reduce the risk and severity of acute mountain sickness [7]. As energy balance is so hard to maintain in the difficult conditions encountered on the mountain, the bottom line advice for alpinists should be to keep intake as high as possible. 


\section{Intestinal function}

Hamad and Travis [1] cite the seminal book of Ward $e t$ al. [8] to argue that above $5500 \mathrm{~m}$ hypoxia-induced malabsorption may play a role in the negative energy balance at high altitude. However, the evidence is not very strong. The few studies that actually measured energy digestibility at high altitude, using bomb calorimetry of faeces, have all reported that the excellent low altitude energy digestibility levels of approximately $95 \%$ are well maintained up to altitudes of $6500 \mathrm{~m}$ in the field $[9,10]$, and even during a simulated Everest climb in a hypobaric chamber [11]. The only field evidence for reduced energy digestibility comes from the American Research Expedition to Mount Everest, when Boyer and Blume reported increased fat levels in faeces collected from climbers at $6300 \mathrm{~m}$ [12]. On the other hand, as appropriately discussed in detail by Hamad and Travis [1], there is good evidence for changes in intestinal sugar transport in conditions of hypoxia, but the point is that these changes apparently have no impact on overall energy digestibility. A recent study [13] found that in conditions of acute hypoxia an increased sympathetic tone leads to a reduction in the postprandial increase of superior mesenteric artery blood flow. At altitude as compared with low altitude, less blood, which is in addition less saturated with oxygen, thus supplies the gut. But again, as evidenced by the digestibility data discussed above, the gut seems to cope well in spite of hypoxemia and relative ischaemia.

So what could be an explanation for the reported malabsorption? A recent report on intestinal flora changes during a mountaineering expedition to the Himalayas provided an interesting hypothesis [14]. The authors reported changes in intestinal flora and signs of immunological stress in seven climbers in field conditions, of whom five had episodes of diarrhoea. The authors speculated that hypoxia per se had an effect on intestinal flora composition, but could not distinguish between altitude, exertion, changes in nutrition and exposure to different bacterial strains while in the Himalayas. It thus would seem plausible that in actual field conditions changes in intestinal flora leading to clinical or subclinical infection malabsorption might become apparent.

\section{Energy expenditure}

Daily energy expenditure is a function of body size, food intake and physical activity. Body size is a determinant of energy expenditure for maintenance or the basal metabolic rate. Food intake determines diet-induced thermogenesis, as mentioned before, and the remaining part is activity-induced energy expenditure. In situations in which heat production from maintenance, food processing and activity is not sufficient to maintain body temperature at $37^{\circ} \mathrm{C}$, additional heat is generated through non-shivering and shivering thermogenesis. In humans, in well-controlled conditions, hypoxia induces a decrease in energy expenditure, as shown during progressive hypoxia in a hypobaric chamber [11]. Six subjects were studied with doubly labelled water over 31 days at 452-253 Torr, corresponding to $4500-8848 \mathrm{~m}$ altitude. Daily energy expenditure was $1.2 \pm 0.6 \mathrm{MJ} /$ day $(P<0.001)$ lower over the second 15 -day interval spent at the highest altitudes. The decrease in expenditure could partly be explained by the decrease in energy intake of $2.1 \pm 0.7 \mathrm{MJ} /$ day $(P<0.001)$ over the corresponding interval. Assuming diet-induced thermogenesis to be $10 \%$ of intake [15], on average 1.2-0.2 $=1.0 \mathrm{MJ} /$ day was left for a decrease in the other components: basal metabolic rate and activity-induced energy expenditure. Therefore under the thermoneutral and confined conditions of a hypobaric chamber, the overall energy requirement is reduced. In actual field conditions cold exposure and exercise will certainly increase energy requirements when climbing at high altitude, as discussed by Hamad and Travis [1]. Energy expenditure in men climbing Mount Everest was $14.7 \mathrm{MJ} /$ day compared with $12.1 \mathrm{MJ} /$ day for similar individuals while staying in a hypobaric chamber at $7000-8000 \mathrm{~m}$ [16]. It is noteworthy that these levels are not extraordinarily high but correspond to levels of active individuals at low altitude. At high altitude the perceived levels of effort are very high, but the actual levels of energy expenditure are in fact quite low because maximum oxygen consumption is curtailed in proportion to altitude, so that on the summit of Everest slow walking corresponds to maximum exercise capacity. However, in spite of these low levels of energy expenditure the duration of exertion is sufficiently long to induce energy misbalance.

If the energy expenditure in the men climbing Mount Everest and in the hypobaric chamber at $7000-8000 \mathrm{~m}$ was $14.7 \pm 1.1 \mathrm{MJ} /$ day and $12.1 \pm 1.8 \mathrm{MJ} /$ day, respectively, clearly showing that the effect of the additional climbing activity on energy expenditure [11,16]; energy intake on Mount Everest and in the hypobaric chamber at $7000-8000 \mathrm{~m}$ was very similar, respectively, $7.9 \pm 1.6$ and $8.3 \pm 1.9 \mathrm{MJ} /$ day. The energy deficit at Mount Everest was thus on average $6.8 \pm 1.7 \mathrm{MJ} /$ day compared with $3.9 \pm 1.4 \mathrm{MJ} /$ day in the hypobaric chamber. The rate of change of body mass was approximately twice as high climbing than being sedentary at the simulated altitude of $7000-8000 \mathrm{~m}$, i.e. respectively, $-0.22 \pm 0.06 \mathrm{~kg} /$ day and $-0.09 \pm 0.05 \mathrm{~kg} /$ day.

The overall conclusion must be that energy intake is the dominant determinant of body weight loss under hypoxic conditions at high altitude. An increased energy requirement through exercise further deteriorates the negative energy balance, as exercise does not seem to elicit a corresponding increase in energy intake. As discussed by Hamad and Travis [1] this negative energy balance necessarily leads to a loss of body mass, partitioned 
between fat and lean mass, of which the reported proportions vary depending on the duration of the exposure to hypoxia, the initial body composition and the level of physical activity.

\section{Conclusion}

Altitude has a profound impact on energy balance and body composition. Hypoxia clearly plays a key role, but especially in field conditions the interplay between changes in dietary habits, in activity patterns, and an exposure to foreign pathogens is not easy to disentangle. Up to altitudes of $5000-6000 \mathrm{~m}$ sojourners should be advised to eat a diet high in carbohydrate and fat, according to personal taste, but rather low in protein, aiming at maintaining energy balance. The length of stay and duration of endurance exercise at higher altitudes should be kept limited. Climbing at very high altitude thus truly seems a difficult balancing act, keeping exercise levels high enough to prevent the detrimental effects of detraining and low enough to keep energy misbalance limited.

\section{Conflict of interest}

None declared.

\section{References}

1 Hamad N, Travis S. Weight loss at high altitude: pathophysiology and practical implications. Eur J Gastroenterol Hepatol 2005; 18:5-10.

2 Woods SC. The eating paradox: how we tolerate food. Psychol Rev 1996; 98:488-505.
3 Cochrane WJ, Afolabi OA. Investigation into the nutritional status, dietary intake and smoking habits of patients with chronic obstructive pulmonary disease. J Hum Nutr Diet 2004; 17:3-11.

4 Tappy L. Thermic effect of food and sympathetic nervous system activity in humans. Reprod Nutr Dev 1996; 36:391-397.

5 Brouwer E. On simple formulae for calculating the heat expenditure and the quantities of carbohydrate and fat oxidized in metabolism of men and animals, from gaseous exchange (oxygen intake and carbonic acid output) and urine-N. Acta Physiol Pharmacol Neerlandica 1957; 6:795-802.

6 Lawless NP, Dillard TA, Torrington KG, Davis Q, Kammimori G. Improvement in hypoxemia at 4600 meters of simulated altitude with carbohydrate ingestion. Aviat Space Environ Med. 1999; 70:874-877.

7 Swenson ER, MacDonald A, Vatheuer M, Maks C, Treadwell A, Allen R, Schoene RB. Acute mountain sickness is not altered by a high carbohydrate diet nor associated with elevated circulating cytokines. Aviat Space Environ Med. 1997; 68:499-503.

8 Ward MP, Milledge JS, West JB.High altitude medicine and physiology, 3rd ed. London: Chapman and Hall; 2000.

9 Kayser B, Acheson K, Decombaz J, Fern E, Cerretelli P. Protein absorption and energy digestibility at high altitude. J Appl Physiol 1992; 73: 2425-2431.

10 Westerterp KR, Kayser B, Wouters L, Le Trong J-L, Richalet J-P. Energy balance at high altitude: $6542 \mathrm{~m}$. J Appl Physiol 1994; 77: 862-866.

11 Westerterp KR, Meijer EP, Rubbens M, Robach P, Richalet J-P. Operation Everest III: energy and water balance. Eur J Physiol 2000; 439: 483-488.

12 Boyer SJ, Blume FD. Weight loss and changes in body composition at high altitude. J App/ Physiol 1984; 57:1580-1585.

13 Loshbaugh JE, Loeppky JA, Greene ER. Effects of acute hypobaric hypoxia on resting and postprandial superior mesenteric artery blood flow. High Alt Med Biol 2005; in press.

14 Kleessen B, Schroedl W, Stueck M, Richter A, Rieck O, Krueger M. Microbial and immunological responses relative to high-altitude exposure in mountaineers. Med Sci Sports Exerc 2005; 37:1313-1318.

15 Westerterp KR. Diet induced thermogenesis. Nutr Metab 2004; 1:1-5.

16 Westerterp KR, Kayser B, Brouns F, Herry JP, Saris WHM. Energy expenditure climbing Mt. Everest. J App/ Physiol 1992; 73: $1815-1819$. 